\title{
Online marketing promotion of local tourism organizations: the analysis of the situation in Moravica administrative district
}

\author{
Dušan Garabinović ${ }^{1 *}$ \\ 1 Higher business school of vocational studies "Prof. dr Radomir Bojković", Kruševac, \\ Serbia
}

\begin{abstract}
Modern information and communication technologies, especially the Internet, have caused many changes that influenced further development of the society, economy and tourism as their integrative part, and will do so in the future. Communication, that is the basis of every promotion, becomes more virtual, digital, online, but its purpose remains the same. Nowadays, even the tourist offer based on highly traditional values should be promoted in a modern way. The institutions of tourism at regional and local levels are much "closer" to the specific product, and such closeness enables better knowledge and understanding. Modern trends in tourism promotion enable local products to reach world proportions and be represented globally. The aim of this paper is to determine the Internet promotion orientation of local tourism organizations from the Moravica administrative district, examine their presence on the Internet in terms of having the official website and social network accounts, and make a comparison between them.
\end{abstract}

Keywords: marketing, promotion, tourism, Internet marketing, local tourism organizations JEL classification: M31, Z30

\section{Onlajn marketing promocija lokalnih turističkih organizacija: analiza stanja u Moravičkom upravnom okrugu}

Sažetak: Savremene informaciono-komunikacione tehnologije, a posebno Internet, dovele su do brojnih promena, promena koje su uticale i uticaće na dalji razvoj ljudskog društva, privrede i turizma kao njihovog sastavnog dela. Komunikacija koja je u osnovi svake promocije postaje sve više virtuelna, digitalna, online, ali njena svrha ostaje ista. U današnje vreme čak i na krajnje tradicionalnim vrednostima zasnovana turistička ponuda mora biti promovisana na savremen način. Turističke institucije na regionalnom i lokalnom nivou mnogo su „bliže“ konkretnom proizvodu, a blizina omogućava njegovo bolje poznavanje i razumevanje. Savremeni trendovi u promovisanju turizma omogućavaju da lokalni proizvodi dosegnu svetske razmere, da budu globalno predstavljeni. Cilj ovog rada je utvrditi kolika je opredeljenost lokalnih turističkih organizacija sa teritorije Moravičkog upravnog okruga promovisanju putem Interneta, kakva je njihova prisutnost na Internetu u smislu postojanja veb-sajta i društvenih mreža, kao i međusobno poređenje turističkih organizacija. 
Ključne reči: marketing, promocija, turizam, Internet marketing, lokalne turističke organizacije

JEL klasifikacija: M31, Z30

\section{Introduction}

Online marketing promotion of local tourism organizations is largely based on the changes caused by information and communication technology development. Therefore, it is necessary to emphasize the novelties that technological solutions have brought into tourism promotion. GlobalData Technology (2018) states six trends to pay attention to in travel and tourism industry: "(1) Augmented and Virtual Reality (AR and VR), (2) Artificial Intelligence (AI), (3) Internet of Things (IoT), (4) Voice technology, (5) Wi-Fi connectivity, and (6) Wearable devices". While we could ask the question "Virtual reality and tourism: fact or fantasy?" in the 1990s (Williams \& Hobson, 1995), it is clear now that not only products of tourism are promoted in this way, but also tourism entered deep into the area of virtual tourism. In addition to the above-mentioned Virtual Reality, AI, chatbots and integration of the IoT, Newman (2018) emphasizes three main transformational trends in catering and tourism: "Mobile Integration, Focus on Data, and Reputation". We should also mention websites, blogs (as specific form of websites), email (mailing list registration included), social networks, Internet forums (discussion groups included), etc; in combination with Location Based Marketing - LBM, Mobile Marketing and electronic Word of mouth marketing - e-WOM Marketing, they all form the foundation of modern approach to potential and existing customers market.

In order to achieve success in modern business for all the subjects in tourism, local tourism organizations included, it is necessary to introduce new technologies - to change. Therefore, we should hold on to our tradition and features, but they should always be "refreshed" with the spirit of the time we live in. Local tourism organizations should provide thorough information on products offered in their territories, at the same time becoming much better acquainted with what they have available. Thus, the analysis of local tourism organizations is the starting point for determining the quality of tourism organization structure in a country such as Serbia, especially in the area of applicable promotion activities.

The subject of this paper is to determine promotion activity representation based on the Internet (websites and social networks) in local tourism organizations in the Moravica district territory. The aim of this paper is to determine the Internet promotion orientation of local tourism organizations from the Moravica administrative district, examine their presence on the Internet in terms of having the official website and social network accounts, and make a comparison between them. The official documents from local governments, districts and tourism organizations (strategies, plans, programs, reports, etc) which refer either completely or partly to the issues in question were used as a source of information about the orientation of local tourism promotion via the Internet. The data available on local tourism organizations' official websites and official accounts on social networks were used as a source of information about real presence of local tourism organizations on the Internet (websites and social networks which are actually in use).

\section{Local tourism organizations online marketing}

According to the Statistical Office of the Republic of Serbia (2018, 14-30), 72.9\% of households in Serbia have an Internet connection (mostly via mobile phones, Tablet or 3G network $67.5 \%$ ), and the number has been on a steady rise in the previous ten years (since 2017 for $4.9 \%$ ), while " $96.4 \%$ of the population between the age of 16 and 24 have an 
account on social networks (Facebook, Twitter)" and $6.4 \%$ of people have ordered accommodation services (hotel) on the Internet in the last 12 months.

In the Tourism Development Strategy 2016-2025, the National Tourism Organization of Serbia "assumes the central role in tourism marketing system in the Republic of Serbia, the role of the mentor and active associate within the entire network of tourism organizations in the country" (The Government of the Republic of Serbia, Ministry of Trade, Tourism and Telecommunications, 2016, 81), which can be at the provincial, regional as well as at the local level. According to that, one of the main activities of the Tourism Organization of Serbia to focus on is "to provide a unique information and communication system in tourism with the application of modern ICT tools" (The Government of the Republic of Serbia, Ministry of Trade, Tourism and Telecommunications, 2016, 81). Therefore, one of the key requirements of well-designed and implemented local tourism organization marketing activities is cooperation with the tourism organization at the national level.

A large number of authors have dealt with the analysis of national tourism organization online marketing activities: Baggio (2003), Giannopoulos \& Mavragani (2011), Zouganeli et al. (2011), Dwivedi et al. (2012), Rojas-Méndez \& Hine (2016), etc. On the other hand, local tourism organizations (often also known as "destination" - DMO), have the same importance as the national ones, and even greater when we speak of tourism products which are not singled out as "the main ones" by the national organization. The Tourism organization of Serbia and Pro Pozitiv agency (n. d.) research results (25th January - 18th March 2016; a sample of 2005 respondents (17\% of population), age 18 and over; territory: 51 municipality) confirmed the attitudes and habits of domestic tourists, including the information that the Internet sites are present in the third place according to usage frequency $(16 \%)$ on destination information. Among the internet sites, local tourism organizations and sites promoting local tourism destination are in the first place according to usage frequency (40\%), without neglecting the role of social networks (Facebook 19\%).

In addition to the above-mentioned websites, local tourism organizations are also largely present on social networks.

\section{Local tourism organizations in Moravica administrative district and online promotion orientation}

The Moravica administrative district consists of four local governments: Čačak, Gornji Milanovac, Ivanjica and Lučani, but only Čačak has the properties of a city. Local tourism organizations in the Moravica administrative district territory (according to the foundation year starting from the oldest one): Tourist organization of Čačak (1997), Tourist organization of Gornji Milanovac municipality (2000), Tourist organization of Ivanjica municipality (2002) and Tourist organization of Lučani municipality "Dragačevo" (2012).

The analysis of Sustainable Strategy Development for Lučani municipality 2011-2021 (Lučani municipality, 2011) and Sustainable Development Strategy for Lučani municipality - Action plan 2015-2020, (Lučani municipality, 2015), leads to the conclusion that tourism promotion is mentioned, but modern technology based promotion is not mentioned. According to the Tourist organization of Lučani municipality report for 2017 (Tourist organization of Lučani municipality "Dragačevo", 2017), it is evident that "new website presentation was created" in April, as well as that the organization helped in the organization of an event in July, with "an advertizing campaign on social networks" among other things. The activity program and plan for 2018 (Tourist organization of Lučani municipality "Dragačevo", 2017) states "appropriately promoted tourism offer" as one of the goals (specific goal 4), but specific modern forms of promotion are not mentioned. 
The Sustainable Development Strategy for Ivanjica municipality 2009-2014 (Ivanjica municipality, 2009) was adopted in Ivanjica in December 2009, but a new strategy was not made afterwards. We can find parts related to tourism promotion within the strategy (Ivanjica municipality, 2009, 17, 18, 27, 29, 52), but its modern forms are not represented at all. The promotion is present in the Tourist Organization of Ivanjica Municipality Report for 2017 (Tourist Organization of Ivanjica Municipality, 2017) in the area of rural tourism featured in the Ivanjica TO website (among other forms), followed by the special part on marketing based on "electronic marketing" among other things. When we speak of modern forms of promotion, we should mention that "interactive showcase was on display in Ivanjica TO premises" in December 2009. There is a special part devoted to electronic marketing where regular website update is mentioned as well as the presence on social networks. In the Activity plan for 2018, a special part within the Marketing plan is devoted to electronic and Internet marketing in the business plan of Ivanjica TO for 2018 (Tourist Organization of Ivanjica Municipality, 2017, 6).

The analysis of the Sustainable Development Strategy for the city of Čačak (the city of Čačak, 2011, 121-124) tourism promotion is mentioned as insufficient and subject to improvement, while, on the other hand, modern forms of tourism potentials promotion are not cited anywhere, although it is obvious that the Internet is the media used by $93.8 \%$ of the respondents as a source of information on products and services, on the basis of the research on information technologies and Internet marketing usage in various promotion strategies in the city of Čačak (Garabinovic \& Papic, 2018a, 67). The respondents most frequently use websites and social networks for information on new or the existing products/services (Garabinovic \& Papic, 2018a, 74-75), they have the best opinion about them and they have the most influence on the product/service purchase (Garabinovic \& Papic, 2018a, 77).

In the Sustainable Development Strategy for Gornji Milanovac municipality 2012-2021 (Gornji Milanovac municipality, 2012), tourist promotion is not mentioned, except as marketing activities (promotion material) for the achievement of the specific goal - the improvement of work in the tourist organization (Gornji Milanovac municipality, 2012, 49, 63), while modern promotion forms are not mentioned at all.

Tourism development program 2012-2022, Inter-municipal partnership of Kraljevo, Raška, Vrnjačka Banja, Gornji Milanovac and Čačak, considers marketing as a constituent part of the mission (“...more efficient marketing..."), but also as a special goal "2. Positioning of the tourist region on the domestic and international market with the authentic products of tourism", where we should emphasize sub-goal 2.2 marketing improvement and better usage of new technology advantages, mainly the Internet through: regional marketing system establishment and marketing strategy development, creation of clear and recognizable region identity, maximum usage of new technologies (the Internet, mobile applications) for promotion as well as sales. There is also centralized development and marketing management among the key factors of success. In the analysis of the Delivery of Quality Experience, we can notice that Marketing and Communication occupy a central place where, among other things, it is stated that "the Internet Usage Plan" is an important form of modern communication.

\section{Research organization}

The research on local tourist organizations' marketing promotion activities representation in the Moravica district territory (TO Čačak, TO Lučani, TO Gornji Milanovac, TO Ivanjica) in terms of having the official website, accounts on chosen social networks (Facebook, Instagram, Twitter and YouTube) as well as their usage during 2018, was conducted on $17^{\text {th }}$ January 2019. The important steps in the research are as follows: (1) to establish whether 
there is the official website; (2) to evaluate the website quality (according to Giannopoulos \& Mavragani, 2011 \& Garabinović \& Papić, 2018b) and compare them; (3) to establish whether there are accounts on chosen social networks according to a) website links and b) social network search, then their comparison; (4) data collection on social networks account activities in 2018 and their comparison. We should remark that the total number of posts also include the posts from other accounts shared through the local tourist organizations official accounts, which has little effect on the number of likes, shares and comments. The total number of likes and shares includes the likes and shares by the local tourist organizations themselves (other accounts). The total number of comments includes all posts, that is, all comments in correspondence (comments, responds to comments, etc, regardless of whether they come from the local tourist organization or some other person).

\section{Results and discussion}

When it comes to the official website analysis, it is determined that each of the four local tourist organizations in the Moravica district territory have one. The analysis has been conducted according to fifteen chosen criteria, and they are presented in table 1 with the results. The criteria are determined on the basis of Giannopoulos \& Mavragani (2011) and Garabinović \& Papić (2018).

Table 1: Website quality evaluation

\begin{tabular}{|c|c|c|c|c|c|c|c|c|c|c|c|c|c|c|c|c|c|}
\hline & & \multicolumn{16}{|c|}{ Criteria } \\
\hline & & $\mathbf{A}$ & B & $\mathrm{C}$ & D & $\mathbf{E}$ & $\mathbf{F}$ & $\mathbf{G}$ & $\mathbf{H}$ & I & $\mathbf{J}$ & $\mathbf{K}$ & $\mathbf{L}$ & $\mathbf{M}$ & $\mathbf{N}$ & $\mathbf{O}$ & Total \\
\hline \multirow{5}{*}{$\begin{array}{l}\text { Local tourism } \\
\text { organizations }\end{array}$} & Čačak & + & + & + & + & + & & & & & & + & + & + & + & + & 10 \\
\hline & $\begin{array}{l}\text { Gornji } \\
\text { Milanovac } \\
\end{array}$ & + & + & + & + & & + & + & & + & & + & + & + & + & + & 12 \\
\hline & Ivanjica & + & + & + & + & + & + & + & & + & & + & & + & + & + & 12 \\
\hline & Lučani & + & + & + & + & & + & + & & + & + & + & + & + & + & + & 13 \\
\hline & Total & 4 & 4 & 4 & 4 & 2 & 3 & 3 & 0 & 3 & 1 & 4 & 3 & 4 & 4 & 4 & \\
\hline
\end{tabular}

Note: $\mathrm{A}$ - Homepage is transparent and easy to read, $\mathrm{B}-$ Important links are on the homepage, $\mathrm{C}-$ Contents are clear, concise, useful and relevant for the audience, $\mathrm{D}-$ The information is grouped in logical units, $\mathrm{E}-$ There is downloadable material, $\mathrm{F}$ - The site contains photos, video and sound effects in addition to the text (at least 2 criteria), $\mathrm{G}$ Horizontal scroll is avoided or minimal, $\mathrm{H}$ - The information describing your position in the site structure appear on each page, I - Site search box is located on the homepage, J Newsletter registration, $\mathrm{K}$ - The site's connection with social network accounts, $\mathrm{L}-$ The site offers possibilities for interaction with visitors (comments, messages), $\mathrm{M}$ - There is a version of the site in a foreign language, $\mathrm{N}$ - The site has links to similar organizations and partners, $\mathrm{O}-$ Posts are regular during the entire year -2018 .

\section{Source: The author's research conducted on $17^{\text {th }}$ January, 2019}

On the basis of the criteria in table 1 and to what extent they are met, we can infer that the Tourist Organization of Lučani municipality has the best website (13/15). We can also notice that most of the criteria $(8 ; 53.33 \%)$ are present in all websites $(100 \%)$, while the worst positioned is newsletter registration $(1 ; 25 \%$, Lučani), as well as the information about your position in the website structure, which does not appear in any of the websites $(0 \%)$. For comparison, the National Tourism Organization of Serbia website (www.srbija.travel) meets all the listed criteria. It is also necessary to mention that English language is the most common among foreign languages (100\%), while German version of the website is only available at the site of Tourist Organization of Čačak (25\%). 
The connection of websites with accounts on social networks (table 2) is evident in all four local tourist organizations (100\%). On the other hand, the search for the accounts on social networks showed a disagreement between website connection with social networks in three local tourist organizations (75\%), the worst in the case of TO Čačak $(50 \%$, that is, $75 \%$ of links lead to the old YouTube account), while only in the case of TO Lučani is there the complete connection of website links with social network accounts.

Table 2: Social networks (website links, accounts existence and usage in 2018)

\begin{tabular}{|c|c|c|c|c|c|c|c|c|c|c|c|c|c|}
\hline & \multicolumn{12}{|c|}{ Social Networks*** } \\
\hline & & \multicolumn{3}{|c|}{ Facebook } & \multicolumn{3}{|c|}{ Twitter } & \multicolumn{3}{|c|}{ Instagram } & \multicolumn{3}{|c|}{ YouTube } \\
\hline & & $\mathrm{A}$ & $\mathrm{B}$ & $\mathrm{C}$ & A & $\mathrm{B}$ & $\mathrm{C}$ & A & $\mathrm{B}$ & $\mathrm{C}$ & $\mathrm{A}$ & B & $\mathrm{C}$ \\
\hline \multirow{4}{*}{$\begin{array}{c}\text { Local } \\
\text { tourism } \\
\text { organizations }\end{array}$} & Čačak & + & + & + & & + & + & & + & + & + & + & + \\
\hline & Lučani & + & + & + & + & + & & + & + & & + & + & + \\
\hline & $\begin{array}{l}\text { Gornji } \\
\text { Milanovac }\end{array}$ & + & + & + & + & + & & & + & + & & + & \\
\hline & Ivanjica & + & + & + & + & + & + & & + & + & & + & + \\
\hline
\end{tabular}

Source: The author's research conducted on $17^{\text {th }}$ January, 2019

It is evident that all the analyzed tourist organizations have open accounts on all four social networks $(100 \%)$ - table 2. However, when it comes to the accounts' usage in 2018 (according to posting criterion - table 2), Facebook is the only one used by all tourist organizations (100\%), while Twitter is the least used (50\%). If we consider 2018, it is clear that only Čačak and Ivanjica tourist organizations (half; 50\%) are the only ones that used all four social networks $(100 \%)$ - the rest used two. According to Papić et al. $(2018,45)$, there was a total of 12 accounts in the Moravica district on $22^{\text {nd }}$ February 2018 (4 less than the current situation - 16), so we should emphasize that new accounts were registered on Instagram by three local tourist organizations - Ivanjica in February, Čačak in August, Gornji Milanovac in September, one on YouTube - Ivanjica in December, as well as new Twitter accounts by the Tourist organization of the Ivanjica municipality (one was registered in 2014 and deactivated at the end of 2018, one registered in June 2018 and one in December 2018 - with the posts following one another). It means that five out of sixteen current accounts on social networks $(31.25 \%)$ were registered in 2018 . Also, it is important to remark that although opened in 2015, YouTube channel of the tourist organization of Čačak had its first post as late as October 2018. From all the above stated, we can say that 2018 was a year with very good results when it came to new account registrations or starting to use certain social networks.

In order to establish the real situation in the usage of certain social networks by tourist organizations in the Moravica administrative district, it is necessary to compare their mutual usage. When we speak of Facebook, which was used by all four local tourist organizations in 2018, the Tourist organization of the Gornji Milanovac municipality had the largest number of followers (4911), the Tourist organization of the Čačak municipality had the largest number of posts (158), likes (3656) and shares (202), while the Facebook page of the Tourist organization of the Lučani municipality had the largest number of comments (80). It is distinctive that the option "event announcement" was used by only two $(50 \%)$ of the organizations (Lučani - 4, Ivanjica - 2). A good summary of the state of things can also be seen in the average values table (table 3). According to this table, the Facebook page of the Tourist organization of the Lučani municipality has the best position when it comes to the number of likes (40.89), shares (2.26) and comments (0.98) per post. The Tourist organization of Čačak had the largest average number of posts per month in 2018 (13.17). The data in table 3 also show that there is no great connection between the number of posts 
and the number of likes, shares and comments. The highest positive correlation can be noticed between the number of likes and shares (about 0.928 ), likes and comments (about 0 . 815), shares and comments (about 0.77), but also between the followers and likes (about 0.742 ), while significant negative correlation is present in relation to event announcement and posts (about -0.692), as well as event announcement and followers (-0.584). Facebook usage data is in Table 3.

Table 3: Facebook usage

\begin{tabular}{|l|c|r|r|r|r|r|r|r|r|r|}
\hline Facebook & $(\mathbf{F})$ & $(\mathbf{E})$ & \multicolumn{1}{c|}{$(\mathbf{P})$} & \multicolumn{1}{c|}{$(\mathbf{L})$} & $(\mathbf{S})$ & $(\mathbf{C})$ & $(\mathbf{L}) /(\mathbf{P})$ & $(\mathbf{S}) /(\mathbf{P})$ & $(\mathbf{C}) /(\mathbf{P})$ & $(\mathbf{P}) / \mathbf{M}^{*}$ \\
\hline Čačak & 3558 & 0 & 158 & 3656 & 202 & 48 & 23.14 & 1.28 & 0.30 & 13.17 \\
\hline Lučani & 2503 & 4 & 82 & 3353 & 185 & 80 & 40.89 & 2.26 & 0.98 & 6.83 \\
\hline $\begin{array}{l}\text { Gornji } \\
\text { Milanovac }\end{array}$ & 4911 & 0 & 104 & 2934 & 126 & 49 & 28.21 & 1.21 & 0.47 & 8.67 \\
\hline Ivanjica & 557 & 2 & 121 & 822 & 77 & 15 & 6.79 & 0.64 & 0.12 & 10.08 \\
\hline
\end{tabular}

Note: (F) - Followers, (E) - Events, (P) - Posts, (L) - Likes, (S) - Shares, (C) -

Comments, $\mathrm{M}^{*}-12$ months

Source: The author's research conducted on $17^{\text {th }}$ January, 2019

Three of the tourist organizations (75\%; Čačak, Gornji Milanovac and Ivanjica) started using Instagram in 2018, as it has already been mentioned, and the only organization already present on the network did not even use it in 2018 (Lučani). Therefore, it comes as no surprise that it took the last place in the number of followers (193). The Instagram account of the Tourist organization of Čačak held a convincing lead in the number of followers (1664; $67.26 \%$ of all the followers); it also held the first place in the number of likes (3470). The Tourist organization of the Ivanjica municipality had a better position in the number of posts (131) and comments (40). The Tourist organization of Čačak' Instagram account was the best positioned when we consider all three average criteria (likes/posts 55.97, comments/posts 0.37 and posts/months 12.4), while Ivanjica was in the second place in two cases (comments/shares 0.31 and posts/months 11.91), Gornji Milanovac in one case (likes/posts 28.39). All the values analyzed (followers, posts, likes and comments) had a positive connection, but significant relations were noticed between posts and comments (about 0.979), likes and comments (about 0.919), posts and likes (about 0.86), followers and likes (about 0.656). The data on Instagram usage is presented in Table 4.

Table 4: Instagram usage

\begin{tabular}{|l|c|c|c|c|c|c|c|}
\hline Instagram & Followers & Posts & Likes & Comments & $\begin{array}{c}\text { Likes/ } \\
\text { posts }\end{array}$ & $\begin{array}{c}\text { Comments/ } \\
\text { Posts }\end{array}$ & $\begin{array}{c}\text { Posts/ } \\
\text { months }\end{array}$ \\
\hline Čačak & 1664 & 62 & 3470 & 23 & 55.97 & 0.37 & 12.4 \\
\hline Lučani & 193 & 0 & 0 & 0 & - & - & - \\
\hline $\begin{array}{l}\text { Gornji } \\
\text { Milanovac }\end{array}$ & 244 & 31 & 880 & 4 & 28.39 & 0.13 & 7.75 \\
\hline Ivanjica & 373 & 131 & 3442 & 40 & 26.27 & 0.31 & 11.91 \\
\hline
\end{tabular}

Note: Number of months in 2018 starting from the Instagram account opening: Ivanjica (11), Čačak (5), Gornji Milanovac (4).

Source: The author's research conducted on $17^{\text {th }}$ January, 2019

Through the analysis of the number of followers on Twitter, it is interesting to notice that the tourist organizations with the largest (Gornji Milanovac 396) and the smallest number of followers (Lučani 1), had no posts in 2018. The Tourist organization of the Ivanjica municipality' Twitter account had the best position according to the number of followers (292 - account opened in 2014, closed at the end of 2018; 25 per new account), posts (131) 
likes (516), shares (198), comments (none for Čačak), average number of likes per post (3.94), shares per post (1.51), comments per post (10.92 - Čačak 0) and posts per month (10.92). It is obvious that there is a large correlation among all the elements analyzed (with the exception of number of followers): likes and shares (about 1), likes and comments (about 1), shares and comments (about 1), posts and shares (about 0.804), posts and likes (about 0.804 ), posts and comments (about 0.802). The data on Twitter usage are presented in Table 5.

Table 5: Twitter usage

\begin{tabular}{|l|c|c|c|c|c|c|c|c|c|}
\hline \multicolumn{1}{|c|}{ Twitter } & $(\mathbf{F})$ & $(\mathbf{P})$ & $(\mathbf{L})$ & $(\mathbf{S})$ & $(\mathbf{C})$ & $(\mathbf{L}) /(\mathbf{P})$ & $(\mathbf{S}) /(\mathbf{P})$ & $(\mathbf{C}) /(\mathbf{P})$ & $(\mathbf{P}) / \mathbf{M}^{*}$ \\
\hline Čačak & 6 & 82 & 2 & 1 & 0 & 0.02 & 0.01 & 0 & 6.83 \\
\hline Lučani & 1 & 0 & 0 & 0 & 0 & - & - & - & - \\
\hline $\begin{array}{l}\text { Gornji } \\
\text { Milanovac }\end{array}$ & 396 & 0 & 0 & 0 & 0 & - & - & - & - \\
\hline Ivanjica & 25 or 292 & 131 & 516 & 198 & 5 & 3.94 & 1.51 & 0.04 & 10.92 \\
\hline
\end{tabular}

Note: F - Followers, P - Posts, L - Likes, S - Shares, C - Comments, M* - 12 months Source: The author's research conducted on $17^{\text {th }}$ January, 2019

As in the case of Instagram, YouTube channel with the largest number of followers (Gornji Milanovac, 156) had no posts in 2018. Considering only the YouTube channels with posts in $2018(3 ; 75 \%)$, we came to the conclusion that only tourist organization of the Lučani municipality had followers (28). The Tourist organization of Čačak had the largest number of posts in the analyzed period (7). Only the Lučani municipality tourist organization recorded likes and comments. It is obvious that there was generally a small number of posts per month - not exceeding 1, while the relation between the number of posts and followers was in negative correlation (about -0.539), regardless of whether we calculated the average number of posts during the entire year or only in one month as in the case of the Tourist organization of the Ivanjica municipality (December). The largest number of reviews, as well as the largest average number of reviews per video in 2018 was in the Tourist organization of Lučani (1701) - one post. The data on YouTube usage are presented in table 6 .

Table 6: YouTube usage

\begin{tabular}{|l|c|c|c|c|c|c|c|}
\hline \multicolumn{1}{|c|}{ YouTube } & Followers & Posts & Likes & Comments & $\begin{array}{c}\text { Average } \\
\text { No. of } \\
\text { posts } \\
\text { per } \\
\text { month }\end{array}$ & $\begin{array}{c}\text { Max. } \\
\text { No. } \\
\text { of } \\
\text { views }\end{array}$ & $\begin{array}{c}\text { Average } \\
\text { No. of } \\
\text { views } \\
\text { per post }\end{array}$ \\
\hline Čačak & 0 & 7 & 0 & 0 & 0.58 & 40 & 24 \\
\hline Lučani & 28 & 1 & 41 & 2 & 0.08 & 1701 & 1701 \\
\hline $\begin{array}{l}\text { Gornji } \\
\text { Milanovac }\end{array}$ & 156 & 0 & 0 & 0 & 0 & 0 & 0 \\
\hline \begin{tabular}{l} 
Ivanjica \\
\hline
\end{tabular} & 1 & 0 & 0 & $\begin{array}{c}0.06 * ; \\
1 * *\end{array}$ & 10 & 10 \\
\hline $\begin{array}{l}\text { Note: * 12 months taken into account; ** } 1 \text { month taken into account (opened in } \\
\text { December 2018) }\end{array}$
\end{tabular}

Source: The author's research conducted on $17^{\text {th }}$ January, 2019

When observed in absolute terms, Facebook is by far the best positioned social network according to all the criteria (followers, posts, likes, shares, comments - all above 50\% share) in three tourist organizations (75\%; Čačak, Lučani and Gornji Milanovac), while in one case (25\%; Ivanjica) it was in the first place only on the basis of the number of followers. In case of the Tourist organization of the Ivanjica municipality, Instagram and Twitter are equal in 
the number of posts; in the number of likes $(72.01 \%)$ and comments $(66.67 \%)$, Instagram is very convincing, but Twitter in the number of shares $(72 \%)$. When it comes to the average number of likes per post, Instagram is in the first place in three tourist organizations $(75 \%$; Čačak, Gornji Milanovac and Ivanjica), while in the case of one (25\%; Lucani), it is YouTube. Facebook has the best position when we speak of the average share number per post in case of three tourist organizations (75\%; Čačak, Lučani and Gornji Milanovac), but in the case of tourist organization of Ivanjica municipality, Twitter is in the first place. The largest average number of comments per post is on Instagram in half of the tourist organizations (2;50\%; Čačak and Ivanjica), while in Lučani it is YouTube $(25 \%)$ and Facebook in Gornji Milanovac (25\%). Facebook is in the first place on the basis of the average number of posts per month in 2018 in three tourist organizations (75\%; Čačak, Lučani and Gornji Milanovac), while in the case of the Tourist organization of the Ivanjica municipality it is Instagram (if we consider the number of months the account existed in 2018), that is, Twitter (if we consider all 12 months).

\section{Conclusion}

Information and communication technologies, the Internet in the first place, represent one of the main components in modern promotion strategies. According to that, online marketing is a part of the Tourism Development Strategy in the Republic of Serbia 2016-2025, and it is one of the key trends in tourism. The activities in tourism in the four local governments of the Moravica district are based on the general strategic documents (for example, sustainable development strategy, etc), where tourism is mentioned, but not the promotion based on modern technologies (with the exception of the Tourism development program 2012-2022, Inter-municipal partnership of Kraljevo, Raška, Vrnjačka Banja, Gornji Milanovac and Čačak). The reports and plans of the local tourist organizations offer, on the other hand, short information about the analyzed form of marketing, whether within the promotion as a unity or as a separate part.

The contribution of this paper is in the analysis of the real characteristics of online promotion activities in local tourist organizations because they are significantly neglected in comparison to the ones at the national level. The main conclusion is that although all four tourist organizations have official websites, there is still enough room for their further improvement (unmet criteria). When we speak of social networks (all four local tourist organizations have accounts on all four social networks), it is necessary to enable better connection to websites (complete connection in only one; 25\%), use them more since only 12/16 social network accounts are used $(75 \% ; 50 \%$ of tourist organizations used all four social networks), improve post quality since the number of shares (max. 2.26) and comments (max. 2; others <1) per post is extremely small, (the number of likes per post is slightly better, but not very large maximum 55.97), which will potentially increase the number of followers (maximum number is 4911). We should still mention the improvement in the account number and usage on social networks compared to February 2018 (Papić et al., 2018, 45), and it is a good signal for further development.

The analysis of the strategic documents and the research conducted on websites and social networks usage in the local tourist organizations of the Moravica administrative district meet the subject and goal of this paper. The focus on the Moravica administrative district alone and the focus on some elements of online marketing (websites and social networks Facebook, Instagram, Twitter and YouTube) are the main restrictions to this paper, and therefore, in order to obtain more complete results, this research should be extended to local tourism organizations from other administrative districts in Serbia (but also in Europe and the world) and to other elements of online marketing, which will be the subject of further 
research. Also, the analysis of the effects of implemented promotional activities on customer behavior can be an interesting subject of future research.

\section{References}

1. Baggio, R. (2003). A websites analysis of European tourism organizations. Anatolia, 14(2), 93-106.

2. Dwivedi, M., Yadav, A., \& Venkatesh, U. (2012). Use of social media by national tourism organizations: A preliminary analysis. Information Technology \& Tourism, 13(2), 92-103. http://dx.doi.org/10.3727/109830512X13258778487353

3. Garabinovic, D., \& Papic, M. (2018a). Analysis of attitudes about the use of information technologies and Internet marketing within different promotional strategies. In Z. Nikitovic, D. Markovic, C. D'Arconte (Eds.), Successful implementation of information technology: IT, marketing, education and business working together for business success (pp. 51-82). London: Silver and Smith Publishers.

4. Garabinović, D., \& Papić, M. (2018b). Primeri upotrebe online marketinga popularnih turističkih manifestacija Moravičkog okruga [Online marketing of popular tourist manifestations in the Moravica county and its tools]. U M. Krstić (Ur.) Zbornik radova Druga nacionalna naučno-stručna konferencija sa međunarodnim učešćem ,,Trendovi u poslovanju 2018“ (pp. 267-280). Kruševac: Visoka poslovna škola strukovnih studija „Prof. dr Radomir Bojković“".

5. Giannopoulos, A. A., \& Mavragani, E. P. (2011). Traveling through the Web: A first step toward a comparative analysis of European national tourism websites. Journal of Hospitality Marketing \& Management, 20(7), 718-739. https://doi.org/10.1080/19368623.2011.577706

6. GlobalData Technology (March 8, 2018) Top 6 technology trends to watch out for in the travel and tourism industry in 2018. Retrieved November 14, 2018. from https://www.globaldata.com/top-6-technology-trends-watch-travel-tourism-industry$\underline{2018 /}$

7. Grad Čačak [The city of Čačak] (2011). Strategija održivog razvoja grada Čačka [Sustainable Development Strategy for the city of Čačak]. Čačak: Grad Čačak.

8. Newman, D. (January 2, 2018). Top 6 Digital Transformation Trends in Hospitality and Tourism. Forbes. Retrieved November 14, 2018 from https://www.forbes.com/sites/danielnewman/2018/01/02/top-6-digital-transformationtrends-in-hospitality-and-tourism/\#1ae78ae567df

9. Opština Gornji Milanovac [Gornji Milanovac municipality] (2012). Strategija održivog razvoja opštine Gornji Milanovac 2012-2021. godine [Sustainable Development Strategy for Gornji Milanovac municipality 2012-2021]. Gornji Milanovac: Opština Gornji Milanovac.

10. Opština Ivanjica [Ivanjica municipality] (2009). Strategija održivog razvoja opštine Ivanjice 2009-2014 [Sustainable Development Strategy for Ivanjica municipality 20092014]. Ivanjica: Opština Ivanjica.

11. Opština Lučani [Lučani municipality] (2011). Strategija održivog razvoja opštine Lučani 2011-2021. [Sustainable Strategy Development for Lučani municipality 20112021]. Lučani: Opština Lučani.

12. Opština Lučani [Lučani municipality] (2015). Strategija održivog razvoja opštine Lučani Akcioni plan 2015-2020. [Sustainable Development Strategy for Lučani municipality - Action plan 2015-2020]. Lučani: Opština Lučani.

13. Papić, M., Garabinović, D., \& Blagojević, M. (2018). An overview of online marketing promotion activities in the event tourism of the Moravica district. Menadžment $u$ 
hotelijerstvu $i$ turizmu - Hotel and Tourism Management, 6(1), 41-51. https://doi.org/10.5937/menhottur1801041P

14. Program razvoja turizma 2012-2022, Međuopštinsko partnerstvo Kraljevo, Raška, Vrnjačka Banja, Gornji Milanovac i Čačak [Tourism development program 2012-2022, Inter-municipal partnership of Kraljevo, Raška, Vrnjačka Banja, Gornji Milanovac and Čačak].

15. Republika Srbija, Republički zavod za statistiku [Statistical Office of the Republic of Serbia] (2018). Upotreba informaciono-komunikacionih tehnologija u Republici Srbiji 2018 [Usage of information and communication technologies in the Republic of Serbia 2018]. Beograd: Republički zavod za statistiku.

16. Rojas-Méndez, J. I. \& Hine, M. J. (2016). Countries' positioning on personality traits: Analysis of 10 South American national tourism websites. Journal of Vacation Marketing, 23(3), 233-247. https://doi.org/10.1177/1356766716649227

17. Turistička organizacija „Dragačevo“ [Tourist organization of Lučani municipality 'Dragačevo'] (2017). Izveštaj o radu za 2017. godinu [Tourist organization of Lučani municipality report for 2017]. Guča: Turistička organizacija „Dragačevo“.

18. Turistička organizacija „Dragačevo“ [Tourist organization of Lučani municipality "Dragačevo"] (2017). Program i plan rada za 2018. godinu [Activity program and plan for 2018]. Guča: Turistička organizacija „Dragačevo“.

19. Turistička organizacija opštine Ivanjica [Tourist Organization of Ivanjica Municipality] (2017). Izveštaj o radu ustanove „Turistička organizacija opštine Ivanjica“ za 2017. godinu [Tourist Organization of Ivanjica Municipality Report for 2017]. Ivanjica: Turistička organizacija opštine Ivanjica.

20. Turistička organizacija opštine Ivanjica [Tourist Organization of Ivanjica Municipality] (2017). Plan rada ustanove „Turistička organizacija opštine Ivanjica“ za 2018. godinu [Activity plan for 2018]. Ivanjica: Turistička organizacija opštine Ivanjica.

21. Turistička organizacija Srbije [Touristic organization of Serbia]. Retrieved January 17, 2019 from www.serbia.travel

22. Turistička organizacija Srbije i ProPozitiv [Tourist organization of Serbia and ProPozitiv] (n.d.). Stavovi i navike domaćih turista u Srbiji 2015 [Domestic tourists' attitudes and habits in Serbia in 2015]. Retrieved December 04, 2018 from http://www.srbija.travel/upload/documents/ProPozitiv\%20i\%20TOS\%20prezentacija\% 20istrazivanja\%20FINAL.pdf

23. Vlada Republike Srbije, Ministarstvo trgovine, turizma i telekomunikacija [The Government of the Republic of Serbia, Ministry of Trade, Tourism and Telecommunications] (2016). Strategija razvoja turizma Republike Srbije 2016.-2025. [Tourism development strategy of the Republic of Serbia 2016-2025].

24. Williams, P. \& Hobson, J. P. (1995). Virtual reality and tourism: fact or fantasy? Tourism Management, 16(6), 423-427. https://doi.org/10.1016/0261-5177(95)00050-X

25. Zouganeli, S., Trihas, N., \& Antonaki, M. (2011). Social media and tourism: the use of Facebook by the European national tourism organizations. Tourism Today, 11, 110-121.

Received: 3 February 2019; Sent for revision: 13 May 2019; Accepted: 15 May 2019 